\title{
Magnesium Oxychloride Cement Composites with MWCNT for the Construction Applications
}

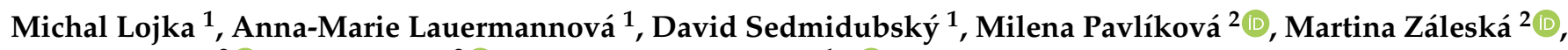 \\ Zbyšek Pavlík ${ }^{2}$, Adam Pivák ${ }^{2}$ and Ondřej Jankovský ${ }^{1, *(1)}$ \\ 1 Department of Inorganic Chemistry, Faculty of Chemical Technology, University of Chemistry and \\ Technology, Technická 5, 16628 Prague 6, Czech Republic; Michal.Lojka@vscht.cz (M.L.); \\ Anna-Marie.Lauermannova@vscht.cz (A.-M.L.); David.Sedmidubsky@vscht.cz (D.S.) \\ 2 Department of Materials Engineering and Chemistry, Faculty of Civil Engineering, Czech Technical \\ University in Prague, Thákurova 7, 16629 Prague 6, Czech Republic; milena.pavlikova@fsv.cvut.cz (M.P.); \\ martina.zaleska@fsv.cvut.cz (M.Z.); pavlikz@fsv.cvut.cz (Z.P.); adam.pivak@fsv.cvut.cz (A.P.) \\ * Correspondence: ondrej.jankovsky@vscht.cz; Tel.: +420-220-44-2002
}

Citation: Lojka, M.; Lauermannová, A.-M.; Sedmidubský, D.; Pavlíková, M.; Záleská, M.; Pavlík, Z.; Pivák, A.; Jankovský, O. Magnesium

Oxychloride Cement Composites with MWCNT for the Construction Applications. Materials 2021, 14, 484 https://doi.org/10.3390/ma14030484

Received: 26 December 2020

Accepted: 18 January 2021

Published: 20 January 2021

Publisher's Note: MDPI stays neutral with regard to jurisdictional claims in published maps and institutional affiliations.

Copyright: (c) 2021 by the authors. Licensee MDPI, Basel, Switzerland. This article is an open access article distributed under the terms and conditions of the Creative Commons Attribution (CC BY) license (https:// creativecommons.org/licenses/by/ $4.0 /)$.

\begin{abstract}
In this contribution, composite materials based on magnesium oxychloride cement (MOC) with multi-walled carbon nanotubes (MWCNTs) used as an additive were prepared and characterized. The prepared composites contained 0.5 and $1 \mathrm{wt} . \%$ of MWCNTs, and these samples were compared with the pure MOC Phase 5 reference. The composites were characterized using a broad spectrum of analytical methods to determine the phase and chemical composition, morphology, and thermal behavior. In addition, the basic structural parameters, pore size distribution, mechanical strength, stiffness, and hygrothermal performance of the composites, aged 14 days, were also the subject of investigation. The MWCNT-doped composites showed high compactness, increased mechanical resistance, stiffness, and water resistance, which is crucial for their application in the construction industry and their future use in the design and development of alternative building products.
\end{abstract}

Keywords: composites; magnesium oxychloride cement; multi-walled carbon nanotube (MWCNT)

\section{Introduction}

The interest in alternative construction materials has been growing continuously in recent decades. Environmentally sustainable composites are being studied more and more and used in practice to reduce the man-made emissions from the industry processes and thus the gradual deterioration of the environment. Large amounts of greenhouse gases (GHG), mainly carbon dioxide, are released during the production of Portland cement (PC) and PC-based composite materials [1]. The search for an alternative for PC has been previously described in the literature, showing the great potential of reactive magnesiabased cement [2-4]. Lately, the interest in reactive magnesia-based cement is mainly focused on magnesium oxychloride cement (MOC).

Magnesium oxychloride cement, also known as Sorel cement, is a term describing cementitious material formed in the $\mathrm{MgO}-\mathrm{MgCl}_{2}-\mathrm{H}_{2} \mathrm{O}$ system [5]. Depending on the reaction temperature and the molar ratio of magnesium oxide and magnesium chloride used as raw materials, four phases are formed in the synthesis. Phase $3\left(3 \mathrm{Mg}(\mathrm{OH})_{2} \cdot \mathrm{MgCl}_{2} \cdot 8 \mathrm{H}_{2} \mathrm{O}\right)$ and Phase $5\left(5 \mathrm{Mg}(\mathrm{OH})_{2} \cdot \mathrm{MgCl}_{2} \cdot 8 \mathrm{H}_{2} \mathrm{O}\right)$ are formed at ambient temperature [6-8], whereas Phase $2\left(2 \mathrm{Mg}(\mathrm{OH})_{2} \cdot \mathrm{MgCl}_{2} \cdot 4 \mathrm{H}_{2} \mathrm{O}\right)$ and Phase $9\left(9 \mathrm{Mg}(\mathrm{OH})_{2} \cdot \mathrm{MgCl}_{2} \cdot 4 \mathrm{H}_{2} \mathrm{O}\right)$ are formed at temperatures above $\sim 100{ }^{\circ} \mathrm{C}$ [9-11]. Previous studies have shown the unique properties of MOC, such as its fire resistance and its resistance to abrasion, as well as its outstanding mechanical properties [12-14]. In comparison to PC, the setting time of MOC is fractional, making it usable as a material that is suitable for quick repairs [15]. The main disadvantage of MOC is its poor water resistance. After interacting with water, MOC structure is destroyed and the high mechanical strength is lost [16]. This problem can be resolved by using various 
additives, which improve the water resistance. The use of soluble phosphates [17], organic acids [18], sewage sludge ash [19], or fly ash [20] for this purpose has been previously described in the literature [21-23].

The main aspect making MOC environmentally sustainable is its so-called $\mathrm{CO}_{2}$ neutrality. When calcining magnesite, which is the main procedure in the production of raw materials for MOC, the temperature is much lower than the calcination temperature of calcite being used in the production process of PC [24-26]. In addition, as previously described in the literature [27], MOC can absorb the atmospheric $\mathrm{CO}_{2} . \mathrm{MOC}$ can be used as a matrix in composite materials with many different fillers, such as silica sand, fly ash, porcelain waste, and others [28,29]. Moreover, additives improving the specific properties of MOC can be used, where those improving the water resistance are mentioned above. Another approach is based on using nanoadditives, namely carbon-based nanoadditives, which improve the mechanical properties of MOC, as has been recently pointed out in the literature [30].

Carbon-based nanomaterials have outstanding mechanical, chemical, and physical properties, which make them applicable as additives in construction materials. Graphene and its derivatives represent the group of 2D carbon nanomaterials that have been previously studied as additives used to improve the mechanical properties of the matrix [31-34]. Single- and multi-walled carbon nanotubes (SWCNTs and MWCNTs) are representatives of $1 \mathrm{D}$ carbon nanomaterials. They are tubular carbon macromolecules containing carbon in the $\mathrm{sp}^{2}$ hybridization. SWCNTs consist of a single sheet of graphite being formed into a seamless tubular shape, while MWCNTs consist of many of these nanotubes constituting concentric circular shapes, similar to the annual rings in a tree trunk $[35,36]$. CNTs exhibit outstanding mechanical, chemical, thermal, and electrical properties [37]. This nanoadditive has been previously used in composite materials to improve their mechanical and electrical properties [38,39]. One of the most useful traits of CNTs is their ability to improve the compressive strength of the composite material. Another quality, which can be improved by the use of CNTs, is the water resistance. This attribute can be quite important when designing novel construction materials [40-44]. The problem of MOC's poor water resistance was mentioned above, and a solution of it could be possibly hidden in the use of small amounts of CNTs.

In this study, a composite material based on MOC with MWCNTs was synthesized and characterized. Two different amounts of CNTs were applied to optimize the most suitable composition of the binder. The synthesized composites were compared to the conventional MOC to evaluate the beneficial effect of the CNTs. The prepared specimens were analyzed in terms of their phase and chemical composition, morphology, thermal behavior, and mechanical properties to help describe their behavior in various environments and applications. This research indicates a possible solution of the poor water resistance of MOC-based materials in general.

\section{Experimental Section}

\subsection{Materials and Synthetic Procedures}

The following chemicals were used for the synthesis: $\mathrm{MgCl}_{2} \cdot 6 \mathrm{H}_{2} \mathrm{O}(>99 \%$, Penta s.r.o., Prague, Czech Republic) and $\mathrm{MgO}$ ( $>80 \%$, Styromagnesit Steirische Magnesitindustrie Ltd., Oberdorf, Austria). The caustic magnesia powder contained $80.4 \mathrm{wt} . \%$ of $\mathrm{MgO}$, 4.3 wt. $\%$ of $\mathrm{SiO}_{2}, 5.0$ wt. $\%$ of $\mathrm{CaO}, 5.8$ wt. $\%$ of $\mathrm{Al}_{2} \mathrm{O}_{3}, 3.9$ wt. $\%$ of $\mathrm{Fe}_{2} \mathrm{O}_{3}$, and less than $1 \mathrm{wt} . \%$ of sulfates. Its BET surface area was $26.07 \mathrm{~m}^{2} \cdot \mathrm{g}^{-1}$, and the particle size distribution parameters were $d_{50}=41.71 \mu \mathrm{m}$ and $d_{90}=65.87 \mu \mathrm{m}$. MWCNTs (TNIM8) were purchased from TimesNano (Chengdu, China) with declared purity $>95 \%$. These MWCNTs were analyzed in detail before their use in composites. The morphology was analyzed using SEM. The micrographs (see Figure 1a) show the typical tubular structure of MWCNTs. The chemical composition was determined by the EDS method. The elemental maps obtained by EDS, as well as the graph showing the quantities of the present elements, are shown in Figure $1 \mathrm{~b}, \mathrm{c}$. Both the maps and the quantitative analysis showed high purity of MWCNTs, 
with more than $98.7 \mathrm{wt} . \%$ content of carbon and only less than $1 \mathrm{wt.} \%$ of aluminum and $\sim 0.3 \mathrm{wt} . \%$ of nickel. Detailed morphology was studied by TEM. The micrographs (see Figure 1d) show the tubes with width in the order of tens of nanometers and lengths up to $20 \mu \mathrm{m}$. The phase composition was determined using X-ray diffraction, showing the specific reflection of MWCNTs at $2 \theta=26.1^{\circ}$ (see Figure 1e). The thermal behavior of MWCNTs was studied using simultaneous thermal analysis (STA) (Figure 1f). The sample was heated to $900{ }^{\circ} \mathrm{C}$ in dynamic air atmosphere. During this process, an exothermic effect occurred at temperatures between $410{ }^{\circ} \mathrm{C}$ and $740{ }^{\circ} \mathrm{C}$, which is connected to the oxidation of the carbon nanotubes. This effect was also accompanied with a significant weight loss, which is clearly visible from the TG curve.
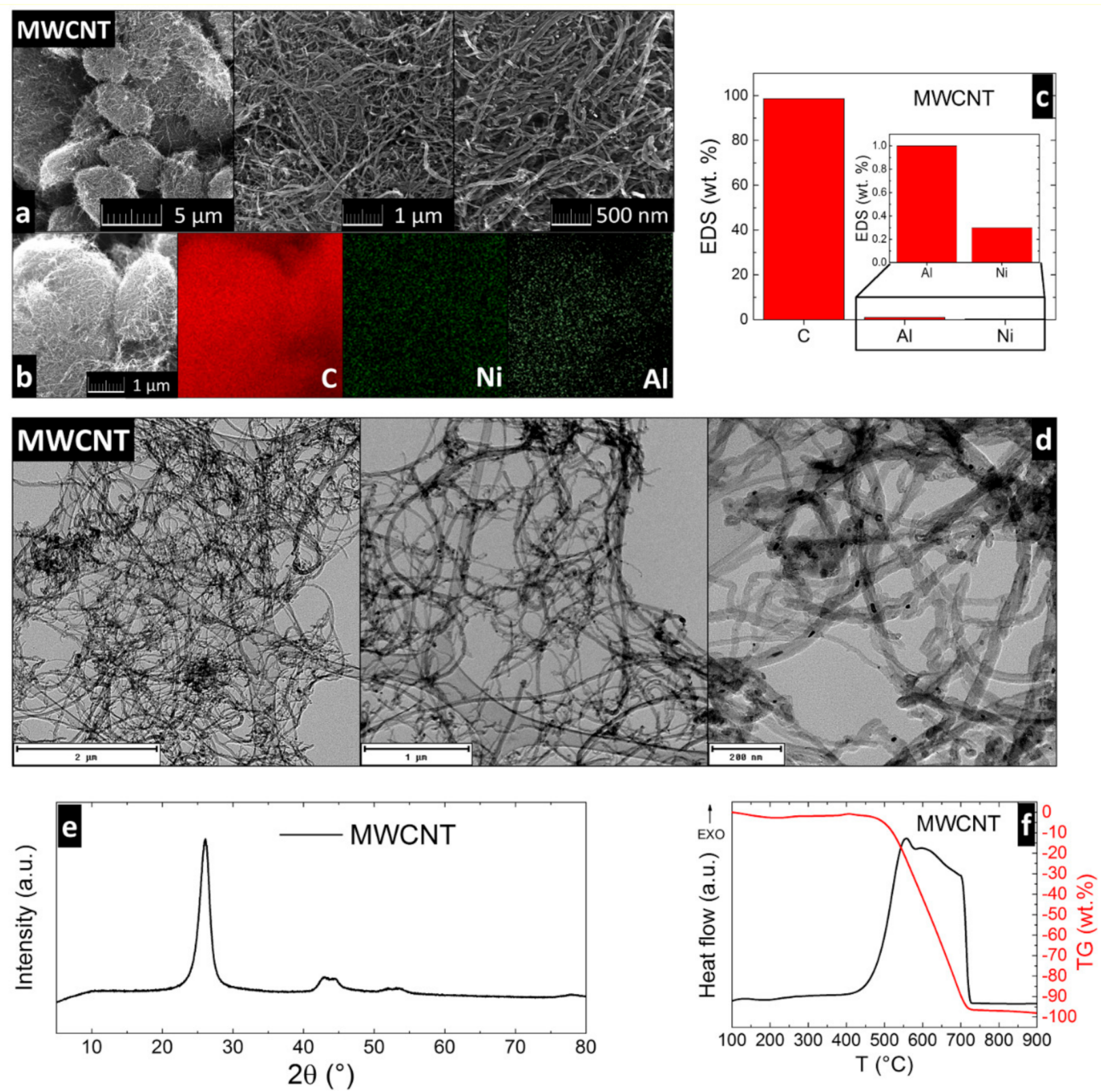

Figure 1. Analysis of multi-walled carbon nanotubes (MWCNTs): (a) SEM micrographs; (b) elemental maps of MWCNTs obtained by EDS; (c) quantity of the elements from EDS; (d) TEM micrographs; (e) diffraction pattern of MWCNTs; and (f) thermal behavior obtained by simultaneous thermal analysis (STA).

The mix proportions of the chemicals used for the synthesis of composites are given in Table 1. The magnesium chloride solution was prepared by dissolving $\mathrm{MgCl}_{2} \cdot 6 \mathrm{H}_{2} \mathrm{O}$ in the tap water. MWCNTs were then sonicated in the part of the prepared $\mathrm{MgCl}_{2}$ solution for $15 \mathrm{~min}$, and the obtained suspensions were used for mixing with $\mathrm{MgO}$ powder. The samples were casted into molds with dimensions of $40 \mathrm{~mm} \times 40 \mathrm{~mm} \times 160 \mathrm{~mm}$, and the samples were demolded after $24 \mathrm{~h}$. The composites were then cured for the next 13 days at laboratory temperatures; $T=(23 \pm 2){ }^{\circ} \mathrm{C}$ in air atmosphere, $\mathrm{RH}=(50 \pm 5) \%$. The resulting samples were termed MOC-CNT-R (reference sample), MOC-CNT-0.5 (0.5 wt. $\%$ of 
MWCNT), and MOC-CNT-1 (1 wt.\% of MWCNT). Let us note that the amount of MWCNT was calculated in relation to the sum of solid raw materials $\left(\mathrm{MgO}\right.$ and $\left.\mathrm{MgCl}_{2} \cdot 6 \mathrm{H}_{2} \mathrm{O}\right)$.

Table 1. Mix proportions of composites (g).

\begin{tabular}{ccccc}
\hline \multirow{2}{*}{ Mixture } & $\mathbf{4}$ Mass $(\mathbf{g})$ \\
\cline { 2 - 5 } & $\mathbf{M g O}$ & $\mathbf{M g C l}_{\mathbf{2}} \cdot \mathbf{6} \mathbf{H}_{\mathbf{2}} \mathbf{O}$ & Water & MWCNT \\
\hline MOC-CNT-R & 1318.6 & 584.1 & 388.3 & 0 \\
MOC-CNT-0.5 & 1318.6 & 584.1 & 388.3 & 9.5 \\
MOC-CNT-1 & 1318.6 & 584.1 & 388.3 & 19.0 \\
\hline
\end{tabular}

\subsection{Analytical Techniques}

To determine the phase composition, X-Ray powder diffraction (XRD) was carried out. Bruker D2 Phaser (Bruker, Karlsruhe, Germany), the powder diffractometer with Bragg Brentano geometry, applying $\mathrm{CuK} \alpha$ radiation $(\lambda=0.15418 \mathrm{~nm}, \mathrm{U}=30 \mathrm{kV}, \mathrm{I}=10 \mathrm{~mA})$ and a rotation $(5 \mathrm{r} / \mathrm{min})$, was used. The used angular range was set to $5-80^{\circ}$, and the step size was set to $0.02025^{\circ}(2 \theta)$. The measured data evaluation, as well as the semi-quantitative analysis, was performed using the $X^{\prime}$ Pert Highscore Plus software (v. 3.0.5).

The study of the surface morphology was performed using scanning electron microscopy (SEM) with the Tescan MAIA 3 apparatus (Brno, Czech Republic). The elemental composition and elemental maps were obtained by means of an energy dispersive spectroscopy (EDS) analyzer (X-Max150) with a $20 \mathrm{~mm}^{2}$ SDD detector (Oxford instruments) and AZtecEnergy software 3.0. To manipulate the sample, and in order to ensure the conductivity, carbon conductive tape was used. The setting for both experiments (SEM and EDS) was the same- the electron beam was set to $10 \mathrm{kV}$. The EDS was performed from the fracture surface. All samples were sputtered by $10 \mathrm{~nm}$ of gold in order to increase the surface conductivity (to avoid charging).

The thermal behavior of the samples was analyzed using simultaneous thermal analysis (STA) with the Setsys Evolution apparatus from Setaram (Geneva, Switzerland) with the temperature ramp up to $900^{\circ} \mathrm{C}$ at a heating rate of $10 \mathrm{~K} \cdot \mathrm{min}^{-1}$. The measurements were performed in a dynamic helium atmosphere with a flow rate of $50 \mathrm{~mL} \cdot \mathrm{min}^{-1}$. In order to analyze the gases being evolved during the heating process, the mass spectrometer OmniStarTM from Pffeifer Vacuum (Aßlar, Germany) was used.

The 14-day laboratory cured composites were examined. Experiments, including assessment of the structural, mechanical, thermal, and hygric properties, were performed. In these tests, at least five samples of each composite were tested. The presented values represent the mean values taken from the data obtained for the particular samples.

Among the structural parameters of the hardened composites, bulk density, specific density, and total open porosity were investigated. The bulk density was obtained from the measurement of the dry sample mass and its volume, as prescribed in the EN 1015-10 [45]. The specific density was measured using a helium automatic pycnometer Pycnomatic ATC (Thermoscientific, Milan, Italy), equipped with the automatic temperature control. Based on the knowledge of the bulk density and specific density, the total open porosity of researched materials was determined [46,47]. The combined expanded uncertainty of the fundamental structural parameter assessment was $1.4 \%, 1.2 \%$, and $2.0 \%$ for the bulk density, specific density, and total open porosity tests, respectively. Helium pycnometers Pascal 140 and Pascal 440 (Thermo Fisher Scientific, Waltham, MA, USA) were applied in the pore size distribution analysis. The fragments of originally casted samples, with a typical mass of $\sim 2 \mathrm{~g}$, were measured. To avoid inhomogeneity of samples in contact with the iron mold surface, the inner part of the original prisms was fragmented.

Flexural strength, compressive strength, and the dynamic Young's modulus were the tested mechanical parameters. The standard EN 1015 -11 [48] was followed in the strength tests. The $40 \mathrm{~mm} \times 40 \mathrm{~mm} \times 160 \mathrm{~mm}$ prisms were used in flexural strength testing. The halves of broken prisms were then subjected to the compression load. The 
loaded cross-sections were $40 \mathrm{~mm} \times 40 \mathrm{~mm}$. The expanded combined uncertainty of the realized strength tests was $1.4 \%$. The dynamic Young's modulus was tested using a non-destructive ultrasonic pulse velocity test on Vikasonic apparatus (Schleibinger Geräte, Buchbach, Germany). The Young's modulus was determined with the expanded combined uncertainty of $2.3 \%$.

Since MOC-based materials have been reported to be vulnerable to water-induced damage [49,50], the effect of the CNT incorporation into the MOC matrix on water imbibition and transport was investigated. The tested hygric parameters were 24-h water absorption and water absorption coefficient. In the water absorption measurement, the EN 13755 [51] was followed. The uncertainty of this test was 1.2\%. Based on the free water intake experiment, organized according to the standard EN 1015-18 [52], the water absorption coefficient was calculated using a one-tangent method. The uncertainty in the water absorption coefficient assessment was $1.2 \%$.

Identification of thermo-physical parameters of the examined composites was performed on a transient place source technique using Hot Disk TPS 1500 (Hot Disk AB, Göteborg, Sweden). Before the measurement itself, the probed samples were dried in a vacuum drier at $60{ }^{\circ} \mathrm{C}$. The hot disk testing was conducted at controlled laboratory temperature $T=(23 \pm 2){ }^{\circ} \mathrm{C}$. As declared by the Hot Disk producer, the accuracy of the measurement was better than $5 \%$ and the reproducibility was better than $1 \%$.

\section{Results and Discussion}

Composites composed of MOC and MWCNT were prepared and characterized in detail. The samples MOC-CNT-R, MOC-CNT-0.5, and MOC-CNT- 1 are shown in Figure 2.

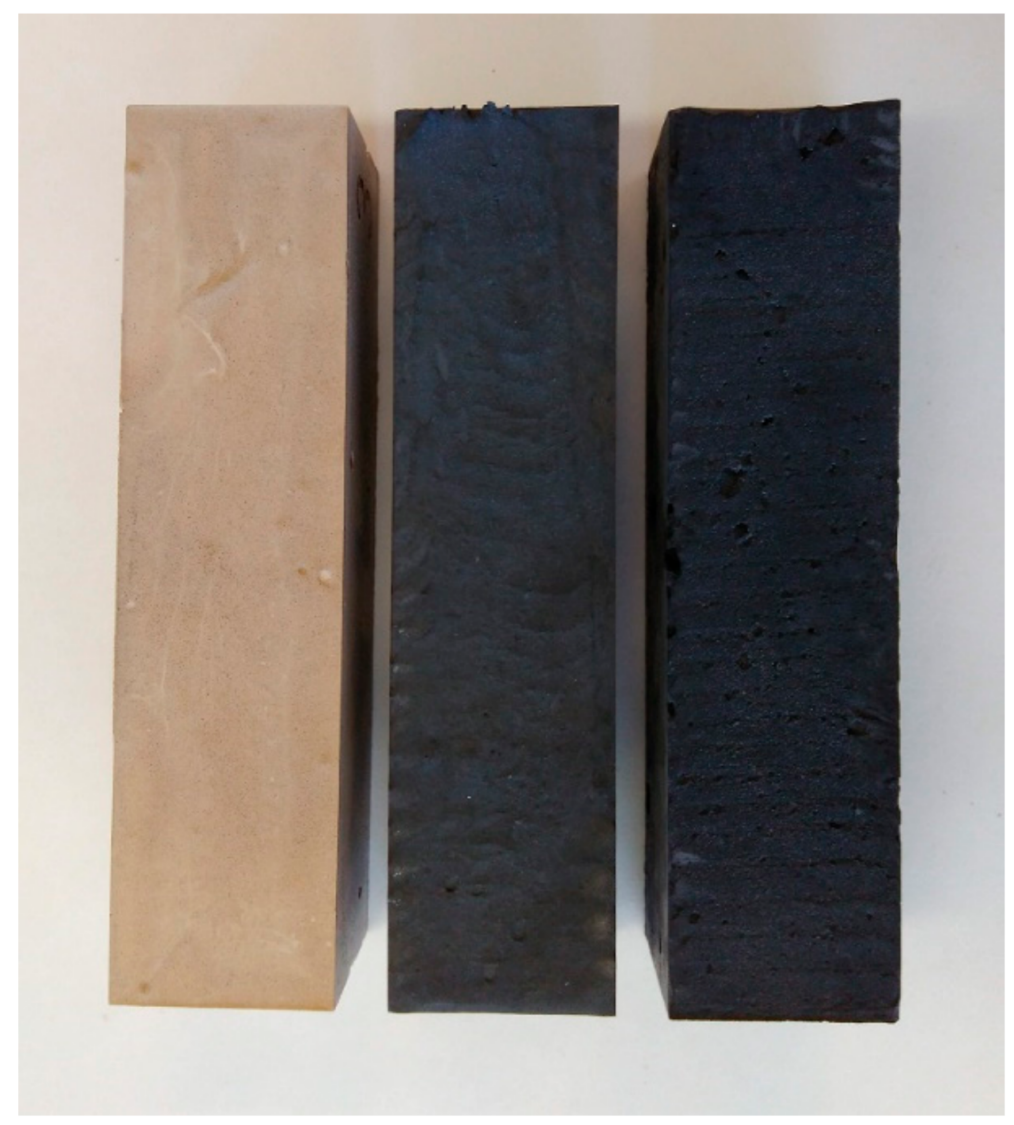

Figure 2. Photograph of the prepared composites MOC-CNT-R (left), MOC-CNT-0.5 (middle), and MOC-CNT-1 (right). 
First, the phase composition of all the samples was studied by XRD. The diffraction patterns of all samples show the presence of the MOC phase 5 (ICDD 04-014-8836) and $\mathrm{MgO}$ (ICDD 04-014-0288). The presence of unreacted magnesium oxide is not problematic, since the residual oxide acts as a filler in this composite material. The MWCNTs were not visible in the diffraction pattern due to their small amount in the sample, in comparison to the other phases. The diffraction patterns of all samples can be seen in Figure 3. These results are in good agreement with the theoretical calculation based on mass balance, where $68 \%$ of $\mathrm{MgO}$ should react and the remaining 32\% should remain unreacted in the form of a filler. The semi-quantitative analysis showed $31 \mathrm{wt} . \%$ content of MgO for MOC-CNT-R, $23 \mathrm{wt}$. \% content of MgO for MOC-CNT-0.5, and $28 \mathrm{wt} . \%$ content of MgO for MOC-CNT- 1.

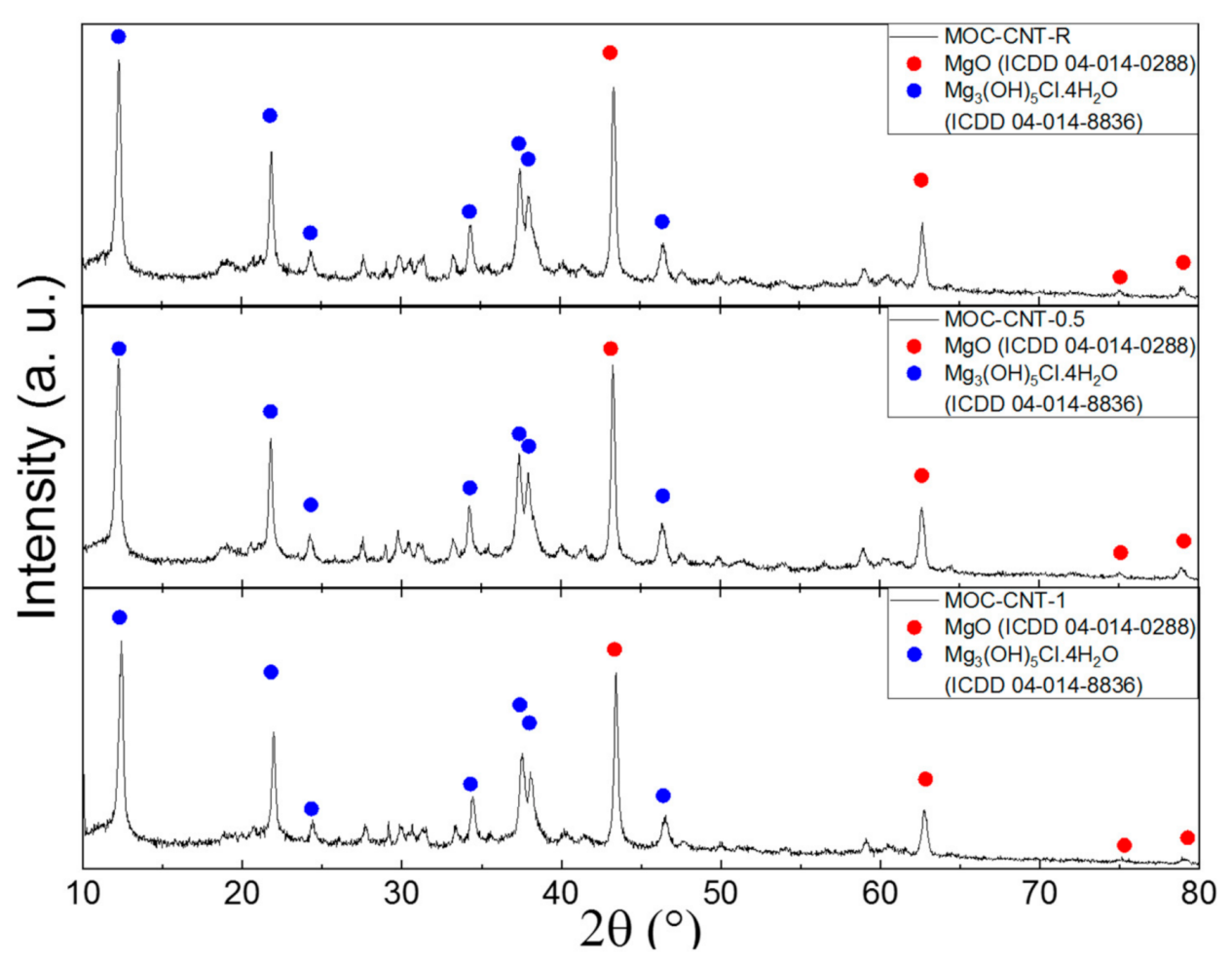

Figure 3. Diffraction patterns of the samples MOC-CNT-R, MOC-CNT-0.5, and MOC-CNT-1.

The microstructure of the samples was analyzed using SEM. All samples showed the presence of needle-shaped crystals, which are typical for MOC. The typical dimensions of the crystals were $1-3 \mu \mathrm{m}$ in length and $\sim 0.5 \mu \mathrm{m}$ in thickness. The SEM micrographs of the composites are displayed in Figure 4.

The chemical composition of the samples was determined using EDS, confirming the expected composition. Apart from magnesium, oxygen, chlorine, and carbon, traces of iron, silicon, and calcium were also detected. These impurities originated from $\mathrm{MgO}$ powder. While magnesium, oxygen, and chlorine were homogeneously distributed on the respective maps, carbon maps revealed carbon-rich areas, suggesting insufficient homogenization of the mixture before casting or, alternatively, a high tendency of MWCNTs to agglomeration. Some carbon was also detected in the reference sample. This might be due to the formation of chlorartinite on the sample surface, which has been previously described in the literature [27]. The elemental maps are shown in the supporting information (Figure S1).

The thermal behavior of the samples was analyzed using STA (Figure 5). The samples were heated from ambient temperature to $900^{\circ} \mathrm{C}$, and their decomposition was observed. Two main effects were identified during the heating - the oxidation of MWCNTs (between $450{ }^{\circ} \mathrm{C}$ and $600{ }^{\circ} \mathrm{C}$ ) and the gradual decomposition of MOC phase 5 throughout the heating process, whose individual steps have been already described in the literature [22]. 
This process mainly consists of a release of crystalline water at lower temperatures and hydrochloric acid at higher temperatures. These endothermal effects are clearly visible on the DTA curve, along with the corresponding weight decrease seen on the TG curve. After the heating, the resulting solid phase after the decomposition is pure magnesium oxide.

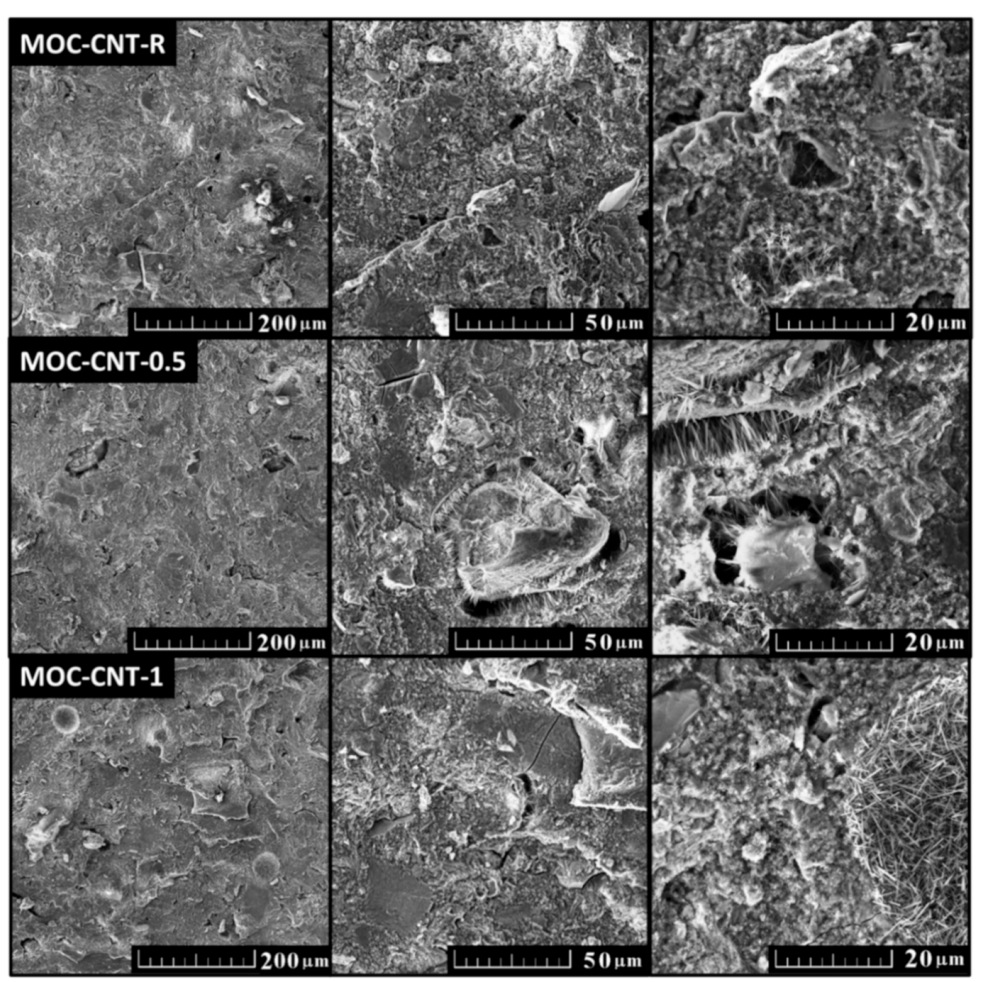

Figure 4. SEM micrographs of the samples MOC-CNT- R, MOC-CNT-0.5, and MOC-CNT-1.
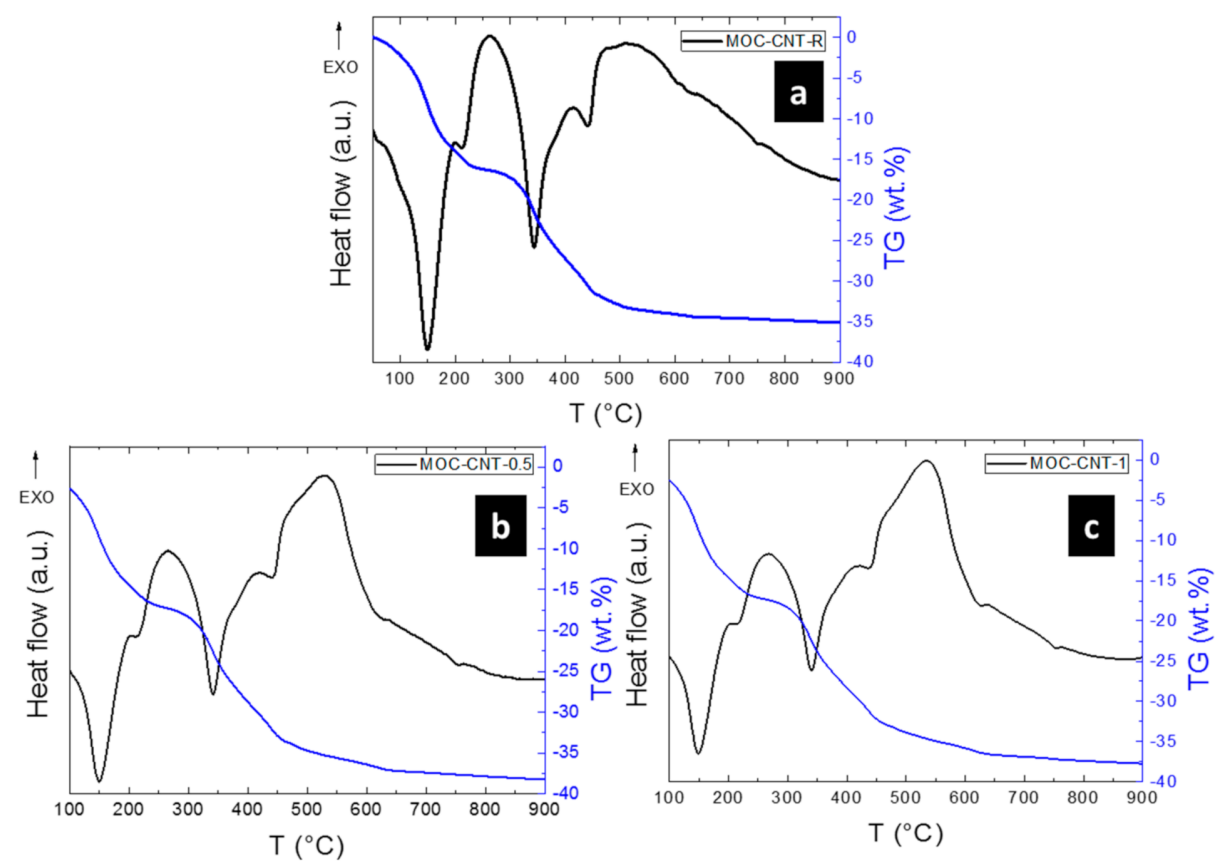

Figure 5. STA of (a) MOC-CNT-R, (b) MOC-CNT-0.5, and (c) MOC-CNT-1. 
The effect of the CNT admixture is apparent from Table 2, where the structural and mechanical parameters of the investigated composites are summarized. The bulk density, specific density, and total open porosity were reduced by the incorporation of CNT into the composite mixture. The most notable drop in porosity was obtained for the MOC-CNT-0.5 composite, whose porosity was decreased by approximately $19 \%$ compared to the reference material MOC-R. The total open porosity of MOC-R-1 was slightly higher than that of MOC-CNT-0.5, which was affected by the formation of CNT agglomerates during the material mixing and setting [53]. On the other hand, the porosity of MOC-CNT-1 was still about $5 \%$ lower in comparison with the control material. The effect of CNT doping on the basic structural parameters is visualized in the supporting information (Figure S2).

Table 2. Basic structural and mechanical properties of the tested composites.

\begin{tabular}{cccc}
\hline Material & MOC-R & MOC-CNT-0.5 & MOC-CNT-1 \\
\hline Bulk density $\rho_{b}\left(\mathrm{~kg} \cdot \mathrm{m}^{-3}\right)$ & $1913 \pm 27$ & $1907 \pm 27$ & $1885 \pm 26$ \\
Specific density $\rho_{s}\left(\mathrm{~kg} \cdot \mathrm{m}^{-3}\right)$ & $1975 \pm 24$ & $1957 \pm 24$ & $1943 \pm 23$ \\
Total open porosity $\Psi(\%)$ & $3.14 \pm 0.06$ & $2.55 \pm 0.05$ & $2.99 \pm 0.06$ \\
Flexural strength $f_{f}(\mathrm{MPa})$ & $14.1 \pm 0.2$ & $15.7 \pm 0.2$ & $16.5 \pm 0.2$ \\
Compressive strength $f_{c}(\mathrm{MPa})$ & $71.4 \pm 1.0$ & $77.5 \pm 1.1$ & $80.2 \pm 1.1$ \\
Young's modulus $E_{d}(\mathrm{GPa})$ & $24.7 \pm 0.6$ & $25.8 \pm 0.6$ & $26.1 \pm 0.6$ \\
\hline
\end{tabular}

All examined materials exhibited high mechanical resistance, which was in agreement with the previously reported results of the mechanical testing of MOC-based products. $[20,54,55]$ The excellent mechanical properties of CNT $[56,57]$ are manifested by the improved mechanical resistance and stiffness of CNT-doped composites. In comparison to the reference material, the flexural strength increased by about $11 \%$ for MOC-CNT-0.5 and by $\sim 17 \%$ for the MOC-CNT- 1 composite. The increase in the compressive strength was approximately $6 \%$ and $12 \%$ for MOC-CNT- 0.5 and MOC-CNT-1, respectively. The stiffness of CNT-enriched materials was also higher than that of the MOC-R reference material. The improvement in mechanical resistance depended, among other effects, on the material porosity. However, in the evaluated mechanical resistance of MOC-CNT materials, the high strength of CNT prevailed over the porosity effect.

Not only the total open porosity, but also the average pore diameter, was decreased by the use of CNT, which documented the refinement of porous space of the CNT-doped composites. The average pore diameters were the following: $0.0076 \mu \mathrm{m}$ (MOC-R), $0.0060 \mu \mathrm{m}$ (MOC-CNT-0.5), and $0.0071 \mu \mathrm{m}$ (MOC-CNT-1). Accordingly, the respective median pore diameters were 0.0078 (MOC-R), 0.0056 MOC-CNT-0.5), and $0.0070 \mu \mathrm{m}$ (MOC-CNT-1). The incremental and cumulative curves of pore size distribution are graphed in Figures 6 and 7 .

The hygrothermal function of the developed composites is apparent in Table 3. The hydrophobic performance of CNT [58] in the contact with water molecules significantly decreased, as documented on both observed hygric parameters. This result is very promising because of high susceptibility of MOC materials to moisture damage. As the water ingress was strongly reduced by the use of CNT in composite mixtures, the better durability of the final materials can be expected. The difference in the thermal conductivity of the studied materials was small, but the effect of highly conducting CNT was very visible. Typically, the higher dosage of CNT increased the thermal conductivity of MOC-CNT-0.5 and MOC-CNT-1 materials as a result of the enormous thermal conductivity of CNT [59]. Accordingly, the volumetric heat capacity of MOC-CNT-1 composites was the highest. 


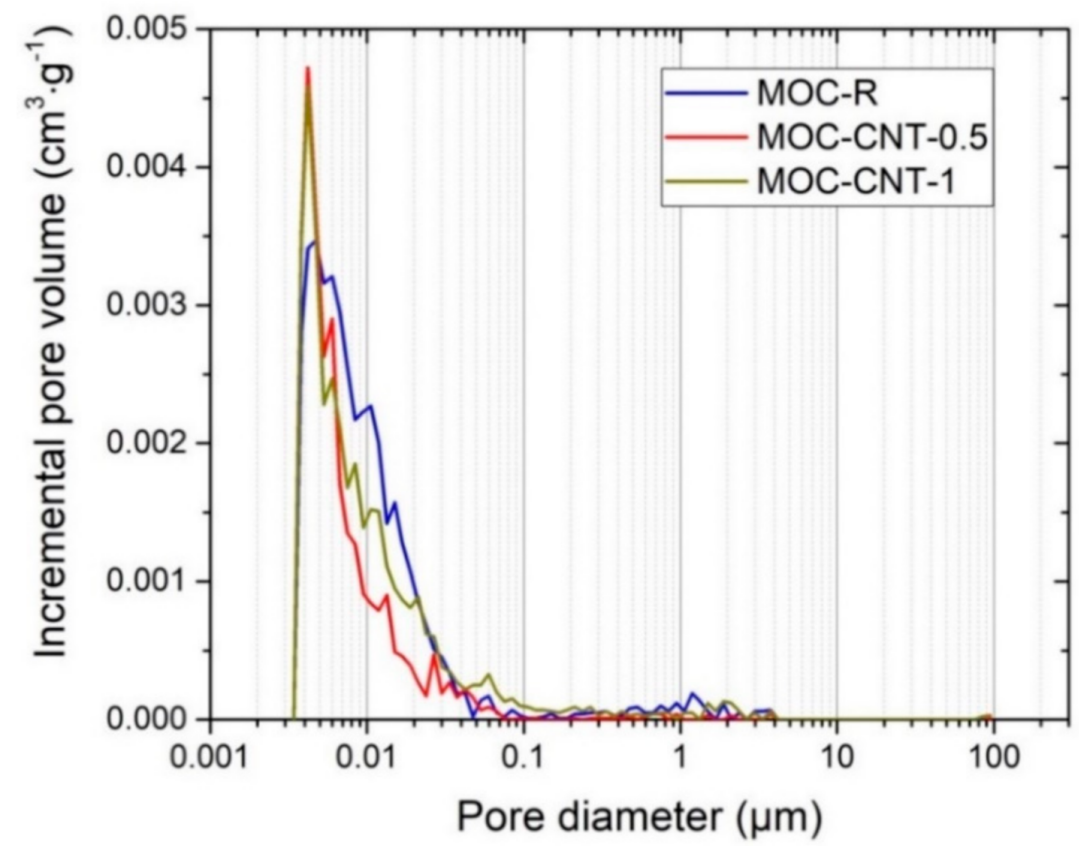

Figure 6. Incremental pore volume distribution of the investigated composites.

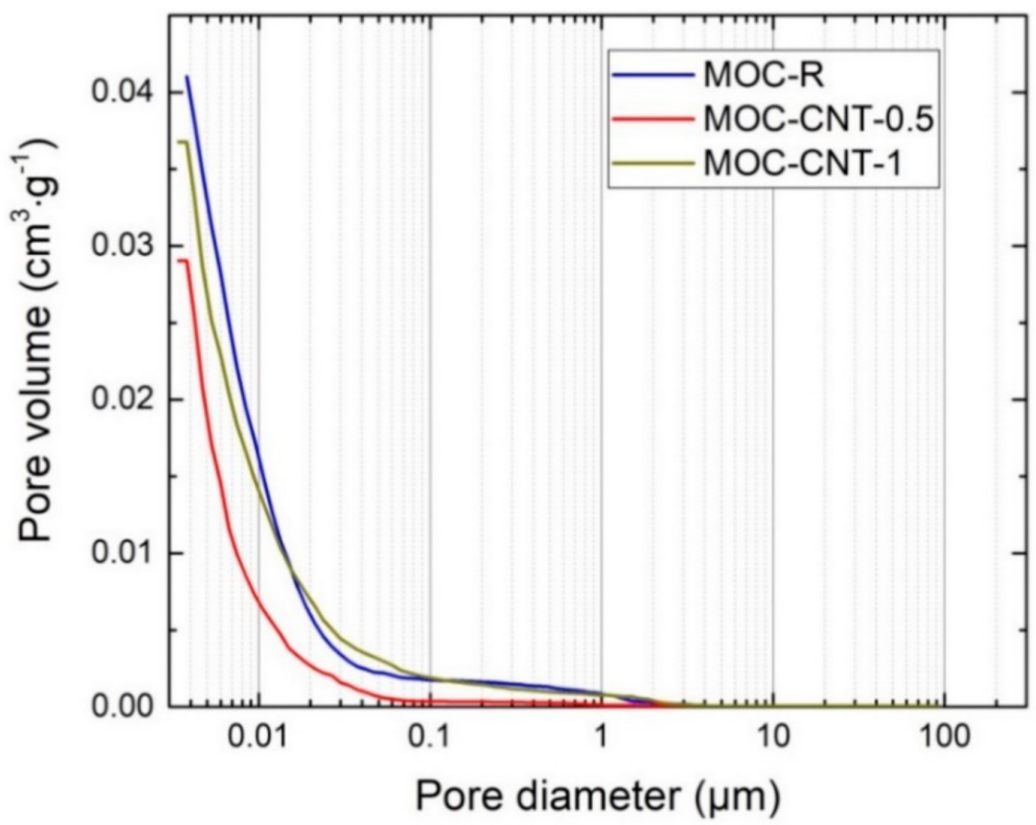

Figure 7. Cumulative pore volume of the investigated composites.

Table 3. Hygric and thermal parameters of the tested composites.

\begin{tabular}{cccc}
\hline Parameter & MOC-R & MOC-CNT-0.5 & MOC-CNT-1 \\
\hline 24-h water absorption (\%) & $1.19 \pm 0.01$ & $1.06 \pm 0.01$ & $1.05 \pm 0.01$ \\
Water absorption coefficient & 0.0016 & 0.0010 & 0.0008 \\
$\left(\mathrm{~kg} \cdot \mathrm{m}^{-2} \cdot \mathrm{s}^{-1 / 2}\right)$ & 1.519 & 1.531 & 1.618 \\
Thermal conductivity $\left(\mathrm{W} \cdot \mathrm{m}^{-1} \cdot \mathrm{K}^{-1}\right)$ & 0.772 & 0.811 & 0.802 \\
Thermal diffusivity $\times 10^{-5}\left(\mathrm{~m}^{2} \cdot \mathrm{s}^{-1}\right)$ & 1.967 & 1.888 & 2.010 \\
Volumetric heat capacity $\times 10^{5}$ & & \\
$\left(\mathrm{~J} \cdot \mathrm{m}^{-3} \cdot \mathrm{K}^{-1}\right)$ & & & \\
\hline
\end{tabular}




\section{Conclusions}

In this contribution, the impact of multi-walled carbon nanotubes on a magnesium oxychloride-based binder was studied. Samples of MWCNT-doped MOC composite were prepared in various weight ratios and characterized in terms of their phase and chemical composition, morphology, thermal behavior, and mechanical properties. We decided to use MWCNTs due to their higher tensile strength and larger diameter compared to SWCNTs. We believe that MWCNTs are more suitable for interaction/cross-linking with MOC. The data gained from the conducted analyses and tests enabled us to point out the following most substantial findings:

(i). Stable and durable MOC phase 5, formed properly and with no crystalline impurities, were present in the sample (except for the parent $\mathrm{MgO}$ acting as a filler);

(ii). The structure of the developed composites was highly compacted without any visible defects;

(iii). The thermal behavior of the hardened materials was presumably comparable to the behavior of MOC phase 5 alone, with the exception of MWCNT oxidation, which was observed in the temperature region between $450-600{ }^{\circ} \mathrm{C}$;

(iv). The MWCNT-doped composites exhibited increased mechanical resistance and stiffness, which was due to the lower porosity, average particles size, and excellent mechanical parameters of MWCNT;

(v). The incorporation of MWCNTs resulted in greatly reduced water ingress. which is positive for material durability in the presence of moisture;

(vi). The heat transport and storage were moderately increased by the incorporation of MWCNTs into the composites.

Based on the obtained results, it can be concluded that the developed composites enriched with MWCNTs possess interesting functional and technical properties, which give them a potential for a wide variety of applications in the construction industry and, in some specific cases, enable us to substitute Portland cement-based products.

The high mechanical resistance of the researched composites represents a good prerequisite for their use in combination with a high volume of inorganic fillers, such as diatomite, foam glass granules, perlite, expanded clay granulate, etc. This will aim to achieve high quality and high-performance materials for specific use.

In consideration of the improved mechanical resistance and greatly dropped water absorption, the economic viability of the use of MWCNTs in the doping of the MOC matrix can be considered as very promising. The incorporation of $0.5 \mathrm{wt} . \%$ and $1 \mathrm{wt} . \%$ of MWCNTs in composite composition enhanced the compressive strength of approximately $11 \%$ and $17 \%$, whereas the price increase of the produced materials was approximately $0.05 \mathrm{USD} / \mathrm{dm}^{3}$ and $0.10 \mathrm{USD} / \mathrm{dm}^{3}$, respectively. Moreover, for the MWCNT-doped materials, the reduced water softening can be anticipated.

Supplementary Materials: The following are available online at https:/ /www.mdpi.com/1996-1 944/14/3/484/s1, Figure S1: Elemental maps of the samples MOC-CNT-R, MOC-CNT-0.5 and MOC-CNT-1, Figure S2: Reduction of the macrostructural parameters (Total open porosity in red, bulk density in gold and specific density in blue) of MOC-CNT-0.5 and MOC-CNT-1 composites due to the CNT admixture.

Author Contributions: Conceptualization, O.J., M.P., and Z.P.; methodology, D.S., M.P., Z.P., and O.J.; investigation, A.-M.L., M.L., M.Z., and A.P.; data curation, D.S., M.P., Z.P., and O.J.; writingoriginal draft preparation, M.L., D.S., A.-M.L., Z.P., and O.J.; supervision, M.P., Z.P., and O.J.; project administration, M.P. and O.J. All authors have read and agreed to the published version of the manuscript.

Funding: This research was funded by the CZECH SCIENCE FOUNDATION, grant No 20-01866S.

Institutional Review Board Statement: Not applicable.

Informed Consent Statement: Not applicable. 
Data Availability Statement: The data presented in this study are available on request from the corresponding author. Additional data are present in Supporting Information file.

Conflicts of Interest: The authors declare no conflict of interest.

\section{References}

1. Huntzinger, D.N.; Eatmon, T.D. A life-cycle assessment of portland cement manufacturing: Comparing the traditional process with alternative technologies. J. Clean. Prod. 2009, 17, 668-675. [CrossRef]

2. Ruan, S.; Unluer, C. Comparative life cycle assessment of reactive $\mathrm{MgO}$ and portland cement production. J. Clean. Prod. 2016, 137, 258-273. [CrossRef]

3. Liska, M.; Al-Tabbaa, A. Ultra-green construction: Reactive magnesia masonry products. Proc. Inst. Civ. Eng. Waste Resour. Manag. 2009, 162, 185-196. [CrossRef]

4. Al-Tabbaa, A. Reactive magnesia cement. In Eco-Efficient Concrete; Pacheco-Torgal, F., Jalali, S., Labrincha, J., John, V.M., Eds.; Woodhead Publishing: Cambridge, UK, 2013; pp. 523-543.

5. Bilinski, H.; Matkovic, B.; Mazuranic, C.; Zunic, T.B. The formation of magnesium oxychloride phases in the systems MgO$\mathrm{MgCl}_{2}-\mathrm{H}_{2} \mathrm{O}$ and $\mathrm{NaOH}-\mathrm{MgCl}_{2}-\mathrm{H}_{2}$ O. J. Am. Ceram. Soc. 1984, 67, 266-269. [CrossRef]

6. Urwongse, L.; Sorrell, C.A. The system $\mathrm{MgO}-\mathrm{MgCl}_{2}-\mathrm{H}_{2} \mathrm{O}$ at $23^{\circ} \mathrm{C}$. J. Am. Ceram. Soc. 1980, 63, 501-504. [CrossRef]

7. Christensen, A.N.; Norby, P.; Hanson, J.C. Chemical reactions in the system $\mathrm{MgO}-\mathrm{MgCl}_{2}-\mathrm{H}_{2} \mathrm{O}$ followed by time-resolved synchrotron X-ray powder diffraction. J. Solid State Chem. 1995, 114, 556-559. [CrossRef]

8. Matkovic, B.; Popovic, S.; Rogic, V.; Zunic, T.; Young, J.F. Reaction products in magnesium oxychloride cement pastes. System $\mathrm{MgO}-\mathrm{MgCl}_{2}-\mathrm{H}_{2} \mathrm{O}$. J. Am. Ceram. Soc. 1977, 60, 504-507. [CrossRef]

9. Dinnebier, R.E.; Freyer, D.; Bette, S.; Oestreich, M. $9 \mathrm{Mg}(\mathrm{OH})_{2} \cdot \mathrm{MgCl}_{2} \cdot 4 \mathrm{H}_{2} \mathrm{O}$, a high temperature phase of the magnesia binder system. Inorg. Chem. 2010, 49, 9770-9776. [CrossRef]

10. Dinnebier, R.E.; Oestreich, M.; Bette, S.; Freyer, D. $2 \mathrm{Mg}(\mathrm{OH})_{2} \cdot \mathrm{MgCl}_{2} \cdot 2 \mathrm{H}_{2} \mathrm{O}$ and $2 \mathrm{Mg}(\mathrm{OH})_{2} \cdot \mathrm{MgCl}_{2} \cdot 4 \mathrm{H}_{2} \mathrm{O}$, two high temperature phases of the magnesia cement system. Z. Anorg. Allg. Chem. 2012, 638, 628-633. [CrossRef]

11. Pannach, M.; Bette, S.; Freyer, D. Solubility equilibria in the system $\mathrm{MgO}-\mathrm{MgCl}_{2}-\mathrm{H}_{2} \mathrm{O}$ from 298 to 393 K. J. Chem. Eng. Data 2017, 62, 1384-1396. [CrossRef]

12. Montle, J.F.; Mayhan, K.G. The role of magnesium oxychloride as a fire-resistive material. Fire Technol. 1974, 10, 201-210. [CrossRef]

13. Xu, B.; Ma, H.; Hu, C.; Yang, S.; Li, Z.J.C.; Materials, B. Influence of curing regimes on mechanical properties of magnesium oxychloride cement-based composites. Constr. Build. Mater. 2016, 102, 613-619. [CrossRef]

14. Beaudoin, J.J.; Ramachandran, V.S. Strength development in magnesium oxychloride and other cements. Cem. Concr. Res. 1975, 5, 617-630. [CrossRef]

15. Qiao, H.; Cheng, Q.; Jinlei, W.; Yingying, S. The application review of magnesium oxychloride cement. J. Chem. Pharm. Res. 2014, $6,180-185$

16. Wang, Y.; Wei, L.; Yu, J.; Yu, K. Mechanical properties of high ductile magnesium oxychloride cement-based composites after water soaking. Cem. Concr. Compos. 2019, 97, 248-258. [CrossRef]

17. Deng, D. The mechanism for soluble phosphates to improve the water resistance of magnesium oxychloride cement. Cem. Concr. Res. 2003, 33, 1311-1317. [CrossRef]

18. Luo, X.; Fan, W.; Li, C.; Wang, Y.; Yang, H.; Liu, X.; Yang, S. Effect of hydroxyacetic acid on the water resistance of magnesium oxychloride cement. Constr. Build. Mater. 2020, 246, 118428. [CrossRef]

19. He, P.; Poon, C.S.; Tsang, D.C.W. Using incinerated sewage sludge ash to improve the water resistance of magnesium oxychloride cement (MOC). Constr. Build. Mater. 2017, 147, 519-524. [CrossRef]

20. Guo, Y.; Zhang, Y.; Soe, K.; Hutchison, W.D.; Timmers, H.; Poblete, M.R. Effect of fly ash on mechanical properties of magnesium oxychloride cement under water attack. Struct. Concr. 2020, 21, 1181-1199. [CrossRef]

21. Feng, C.; Guimarães, A.S.; Ramos, N.; Sun, L.; Gawin, D.; Konca, P.; Hall, C.; Zhao, J.; Hirsch, H.; Grunewald, J.; et al. Hygric properties of porous building materials (VI): A round robin campaign. Build. Environ. 2020, 185, 107242. [CrossRef]

22. Jirickova, A.; Lojka, M.; Lauermannova, A.M.; Antonacik, F.; Sedmidubsky, D.; Pavlikova, M.; Zaleska, M.; Pavlik, Z.; Jankovsky, O. Synthesis, structure, and thermal stability of magnesium oxychloride $5 \mathrm{Mg}(\mathrm{OH})_{2} \cdot \mathrm{MgCl}_{2} \cdot 8 \mathrm{H}_{2} \mathrm{O}$. Appl. Sci. 2020, 10, 15 . [CrossRef]

23. Lojka, M.; Jankovský, O.; Jiřičková, A.; Lauermannová, A.-M.; Antončík, F.; Sedmidubský, D.; Pavlík, Z. Thermal stability and kinetics of formation of magnesium oxychloride phase $3 \mathrm{Mg}(\mathrm{OH})_{2} \cdot \mathrm{MgCl}_{2} \cdot 8 \mathrm{H}_{2} \mathrm{O}$. Materials 2020, 13, 767. [CrossRef] [PubMed]

24. Eubank, W.R. Calcination studies of magnesium oxides. J. Am. Ceram. Soc. 1951, 34, 225-229. [CrossRef]

25. Fischer, H.C. Calcination of calcite: I, Effect of heating rate and temperature on bulk density of calcium oxide. J. Am. Ceram. Soc. 1955, 38, 245-251. [CrossRef]

26. Fischer, H.C. Calcination of calcite: II, Size and growth rate of calcium oxide crystallites. J. Am. Ceram. Soc. 1955, 38, 284-288. [CrossRef]

27. Jankovský, O.; Lojka, M.; Lauermannová, A.-M.; Antončík, F.; Pavlíková, M.; Pavlík, Z.; Sedmidubský, D. Carbon dioxide uptake by MOC-based materials. Appl. Sci. 2020, 10, 2254. [CrossRef] 
28. Pivák, A.; Pavlíková, M.; Záleská, M.; Lojka, M.; Jankovský, O.; Pavlík, Z.J.M. Magnesium oxychloride cement composites with silica filler and coal fly ash admixture. Materials 2020, 13, 2537. [CrossRef]

29. Pivák, A.; Pavlíková, M.; Záleská, M.; Lojka, M.; Lauermannová, A.-M.; Jankovský, O.; Pavlík, Z.J.P. Low-carbon composite based on MOC, silica sand and ground porcelain insulator waste. Processes 2020, 8, 829. [CrossRef]

30. Jankovský, O.; Lojka, M.; Lauermannová, A.-M.; Antončík, F.; Pavlíková, M.; Záleská, M.; Pavlík, Z.; Pivák, A.; Sedmidubský, D. Towards novel building materials: High-strength nanocomposites based on graphene, graphite oxide and magnesium oxychloride. Appl. Mater. Today 2020, 20, 100766. [CrossRef]

31. Chuah, S.; Pan, Z.; Sanjayan, J.G.; Wang, C.M.; Duan, W.H. Nano reinforced cement and concrete composites and new perspective from graphene oxide. Constr. Build. Mater. 2014, 73, 113-124. [CrossRef]

32. Du, H.; Gao, H.J.; Pang, S.D. Improvement in concrete resistance against water and chloride ingress by adding graphene nanoplatelet. Cem. Concr. Res. 2016, 83, 114-123. [CrossRef]

33. Mohammed, A.; Sanjayan, J.G.; Nazari, A.; Al-Saadi, N.T.K. Effects of graphene oxide in enhancing the performance of concrete exposed to high-temperature. Aust. J. Civ. Eng. 2017, 15, 61-71. [CrossRef]

34. Devasena, M.; Karthikeyan, J. Investigation on strength properties of graphene oxide concrete. Int. J. Eng. Sci. Invent. Res. Dev. 2015, 1, 307-310.

35. Khare, R.; Bose, S. Carbon nanotube based composites-A review. J. Miner. Mater. Charact. Eng. 2005, 4, 16. [CrossRef]

36. Baddour, C.E.; Briens, C. Carbon nanotube synthesis: A review. Int. J. Chem. React. Eng. 2005, 3. [CrossRef]

37. Shokrieh, M.M.; Saeedi, A.; Chitsazzadeh, M. Mechanical properties of multi-walled carbon nanotube/polyester nanocomposites J. Nanostruct. Chem. 2013, 3, 20. [CrossRef]

38. Jankovský, O.; Storti, E.; Moritz, K.; Luchini, B.; Jiříčková, A.; Aneziris, C.G. Nano-functionalization of carbon-bonded alumina using graphene oxide and mwcnts. J. Eur. Ceram. Soc. 2018, 38, 4732-4738. [CrossRef]

39. Jankovský, O.; Storti, E.; Schmidt, G.; Dudczig, S.; Sofer, Z.; Aneziris, C.G. Unique wettability phenomenon of carbon-bonded alumina with advanced nanocoating. Appl. Mater. Today 2018, 13, 24-31. [CrossRef]

40. Chen, S.J.; Collins, F.G.; Macleod, A.J.N.; Pan, Z.; Duan, W.H.; Wang, C.M. Carbon nanotube-cement composites: A retrospect. IES J. Part A Civ. Struct. Eng. 2011, 4, 254-265. [CrossRef]

41. Choi, H.; Kang, D.; Seo, G.S.; Chung, W. Effect of some parameters on the compressive strength of MWCNT-cement composites. Adv. Mater. Sci. Eng. 2015, 2015, 340808. [CrossRef]

42. Kim, G.M.; Nam, I.W.; Yang, B.; Yoon, H.N.; Lee, H.K.; Park, S. Carbon nanotube (CNT) incorporated cementitious composites for functional construction materials: The state of the art. Compos. Struct. 2019, 227, 111244. [CrossRef]

43. Yakovlev, G.; Pervushin, G.; Maeva, I.; Keriene, J.; Pudov, I.; Shaybadullina, A.; Buryanov, A.; Korzhenko, A.; Senkov, S. Modification of construction materials with multi-walled carbon nanotubes. Procedia Eng. 2013, 57, 407-413. [CrossRef]

44. Makar, J.; Beaudoin, J. Carbon nanotubes and their application in the construction industry. Spec. Publ. R. Soc. Chem. 2004, 292, 331-342.

45. EN 1015-10. Methods of Test for Mortar for Masonry_Part 10: Determination of Dry Bulk Density of Hardened 676 Mortar; European Committee for Standardization: Brussels, Belgium, 1999.

46. Pavlíková, M.; Zemanová, L.; Pokorný, J.; Záleská, M.; Jankovský, O.; Lojka, M.; Sedmidubský, D.; Pavlík, Z. Valorization of wood chips ash as an eco-friendly mineral admixture in mortar mix design. Waste Manag. 2018, 80, 89-100. [CrossRef]

47. Záleská, M.; Pavlíková, M.; Pokorný, J.; Jankovský, O.; Pavlík, Z.; Černý, R. Structural, mechanical and hygrothermal properties of lightweight concrete based on the application of waste plastics. Constr. Build. Mater. 2018, 180, 1-11. [CrossRef]

48. EN 1015-11. Methods of Test for Mortar for Masonry_Part 10: Determination of Flexural and Compressive Strength 678 of Hardened Mortar; European Committee for Standardization: Brussels, Belgium, 1999.

49. Wei, L.; Wang, Y.; Yu, J.; Xiao, J.; Xu, S. Feasibility study of strain hardening magnesium oxychloride cement-based composites. Constr. Build. Mater. 2018, 165, 750-760. [CrossRef]

50. Wang, L. Study on the water resistance and mechanism of improving for magnesium oxychloride cement with phosphate and polymer. J. Funct. Mater. 2015, 46, 13066-13069.

51. EN 13755. Natural Stone Test Methods: Determination of Water Absorption at Atmospheric Pressure; British Standards Institution: London, UK, 2008.

52. EN 1015-18. Methods of Test for Mortar for Masonry. Part 18: Determination of Water Absorption Coefficient Due to Capillary Action of Hardened Mortar; European Committee for Standardization: Brussels, Belgium, 2002.

53. Adhikary, S.K.; Rudžionis, Ž.; Rajapriya, R. The effect of carbon nanotubes on the flowability, mechanical, microstructural and durability properties of cementitious composite: An overview. Sustainability 2020, 12, 8362. [CrossRef]

54. Jianli, M.; Youcai, Z.; Jinmei, W.; Li, W. Effect of magnesium oxychloride cement on stabilization/solidification of sewage sludge. Constr. Build. Mater. 2010, 24, 79-83. [CrossRef]

55. Hall, D.A.; Stevens, R.; El-Jazairi, B.J.C. The effect of retarders on the microstructure and mechanical properties of magnesiaphosphate cement mortar. Cem. Concr. Res. 2001, 31, 455-465. [CrossRef]

56. Manzur, T.; Yazdani, N.; Emon, M.A.B. Effect of carbon nanotube size on compressive strengths of nanotube reinforced cementitious composites. J. Mater. 2014, 2014, 1-8. [CrossRef]

57. Zu, M.; Lu, W.; Li, Q.-W.; Zhu, Y.; Wang, G.; Chou, T.-W. Characterization of carbon nanotube fiber compressive properties using tensile recoil measurement. ACS Nano 2012, 6, 4288-4297. [CrossRef] [PubMed] 
58. Esmaeilzadeh, H.; Su, J.; Charmchi, M.; Sun, H. Effect of hydrophobicity on the water flow in carbon nanotube-A molecular dynamics study. Theor. Appl. Mech. Lett. 2018, 8, 284-290. [CrossRef]

59. Han, Z.; Fina, A. Thermal conductivity of carbon nanotubes and their polymer nanocomposites: A review. Prog. Polym. Sci. 2011, 36, 914-944. [CrossRef] 